\title{
Steroid Measurement
}

National Cancer Institute

\section{Source}

National Cancer Institute. Steroid Measurement. NCI Thesaurus. Code C75345.

The determination of the amount of any steroid present in a sample. 